\title{
Analisys Of Demand and Optimization Of Medicine Prediction Using ABC Analysis and SVR Method In The "MORBIS" Aplication
}

\author{
Tutik Maryana*1, Kusrini ${ }^{2}$, Hanif Al Fatta ${ }^{3}$ \\ ${ }^{1,2,3}$ Magister Teknik Informatika, Fakultas Ilmu Komputer, Universitas Amikom Yogyakarta \\ E-mail: ${ }^{* 1}$ tutik.maryana@students.amikom.ac.id, ${ }^{2}$ kusrini@ students.amikom.ac.id, \\ hanif.a@amikom.ac.id
}

\begin{abstract}
The problem that occurs in hospitals regarding the processing of drug supplies is about the condition of out of stock medicines because hospitals spend around 33\% of the total investment in one year only for the investment costs of drugs. To deal with the above problems the hospital must have good logistics management, one way of managing it is by doing good planning. In this research, the writer will use ABC Analysis and Support Vector Regression (SVR) algorithm. For the use of these methods, the following ABC Analysis will be used for the drug classification process, namely by dividing the torch into three main groups based on interests, namely groups $A$, $B$ and $C$. Henceforth, the writer will use the SVR motedo to calculate drug predictions. The results that the authors get from this study are ABC analyys classify drugs. Into three groups namely group A with a total of 276 items with a percentage of $22.96 \%$ of the total number of items, group $B$ with a total of 396 items with a percentage of $33.11 \%$ and $C$ with a total of 528 with a percentage of 43.94\% with a total of 1202 drug items. Prediction testing is done by taking a sample of five drugs derived from group classification. The SVR calculation process is done by comparing linear scaling and $z$ normalization preprocessing methods. The result of this research is that MAPE shows that preprocessing with linear scaling produces a better value than compared to $z$ nomrlization and calculation with $A B C$ analysis..
\end{abstract}

Keywords - SVR, classification, prediction, ABC Analyst.

\section{INTRODUCTION}

Medicine is an irreplaceable component in a health service, whether in a hospital, clinic or other health service. Medicines are used to influence or investigate physiological systems or pathological conditions in the process of determining diagnosis, prevention, healing, recovery and health improvement (Kemenkes RI, 2006). One of the determinants of drug access is the availability of drugs in health care facilities.

Drug management is one indicator of the quality of pharmaceutical services. According to Quick et al (2012), the drug management system consists of selection, contribution, procurement and use of drugs. Good drug management must have a system that ensures drug availability in each health service unit. Drug management can be influenced by personnel / human resources, facilities, equipment, costs / prices, administration and information systems. The availability of drugs in fast amounts and types will not only increase access to drugs but will also affect public perceptions about the quality of health services they receive (Bruno et al., 2015).

The average total expenditure (investment) spent by hospitals for managing drug supplies is around 33\% of the total expenditure (investment) overall (Kumar \& Chakravarty, 2015). Seeing that this figure is quite a large number, management is needed. a good supply of drugs because in the end it will affect hospital income (Uthayakumar \& Priyan, 2013). A pharmacy installation in a hospital must manage up to thousands of drugs and almost every day there are transactions with various types of drugs and the amount varies widely ( Laili \& Renny, 2011). The problem that arises in the process of managing drug supplies is that there may be an empty drug stock or stock out, which is a condition where the amount of drug demand is not proportional to the supply in the 
hospital. This condition occurs because of an error. in the planning of supplies between medicinal items (Shiau \& Sheng, 2012).

A review conducted from research conducted by Silviana Agstami in 2014 found that the classification using $\mathrm{ABC}$ Analysis provides more accurate information and is able to show the proposed costs consumed in the production process compared to traditional motedo in the case of drug classification. In addition, research conducted by Rathanaksambath Ly and Marrokot Raweewan in a study entitled Flexible ABC Inventory Classification obtained results that by classifying based on sales in a certain period, it can produce a classification that maximizes profits under conditions of having limited inventory and limited warehouse space.

One of the previous studies used as a reference in this research is research on the diagnosis of breast cancer patients using the binary logistic regression method and Support Vector Regression (SVR). The variables used in the study consisted of the response variable (Y) which was breast cancer patients, and the predictor variable $(\mathrm{X})$ consisted of Intermediate Findings, BIRADS category, Suspicious for Malignancy, Age, and Abnormal Position. With the use of these two methods, the results obtained that the Support Vector Regression (SVR) method will produce an accuracy of $94.34 \%$ greater accuracy than the binary logistic regression method which produces an accuracy of $88.72 \%$ so it can be concluded that the best performance accuracy is using the SVM method. (Novianti \& Purnami, 2012).

Suwardika (2016) conducted research on the grouping and classification of contraceptive use in Indonesia using three methods, namely binary logistic regression, SVM, and Classification and Regression Tree (CART). The data used are secondary data with 1 response variable and 9 predictor variables. The response variable is a binary variable with 2 categories, namely "0" not using and category "1" using. Meanwhile, 9 predictor variables consist of wife's age, wife's education, husband's education, number of children, wife's religion, formal employment status, husband's fertility level, life index standards, and knowledge of family planning acceptors. The results obtained using 3 analytical methods are that classification using the SVM method is better than the other two methods.

Examination of drugs for safe stock in the following month that occurs in the "MORBIS" application is by the end of each month the pharmacy officer calculates the sales of drugs manually using excel. The calculation is done by the officer looking for the monthly average sales of each drug per day and then multiplying it by 30 (the number of days in 1 month). This figure is the basis for submitting the number of drugs needed by the hospital for the next month. Based on this method, it often happens that the estimation or forecasting of the number of drugs submitted often experiences errors and suddenly requests for drug purchases occur. This problem has an impact on the monthly hospital budget plan.

To avoid this, a good supply of medicine is needed. One way that can be done is by doing the prediction method (Fruhhiero, Lannone, Martino, Mirada \& Riemma, 2012). where the method is expected to have the ability to predict future needs (Makridakis, 1986). Before carrying out the forecasting process, the author uses the $\mathrm{ABC}$ Analysis method which is used to help classify items based on the level of importance divided into groups A, B and C. ABC Analysis calculation is based on the level of investment expenditure in one year. This method refers to the Pareto concept (Acholz-Reiter, Heger, Meinecke \& Bergmann, 2012). This study will discuss the process of drug classification using $\mathrm{ABC}$ Analysis, then proceed with drug prediction using the Support Vector Regression (SVR) method. This method is expected to solve the problems that occur in the hospital.

The author has the ABC Analysis method because this method is able to control the inventory of goods by paying attention to the group of goods according to the level of interest of each group of goods, in this method the goods are classified into classes A, B and C based on sales value. So that the company can see the level of importance of these goods.

\section{RESEARCH METHODS}

\subsection{Data Collection}

The data collection method that we do is by collecting primary data, that is, we take data directly from the first data source, namely from the application used to carry out operational activities in the hospital. The data that the authors get is data that is exported directly from the 
database in the form of .dmp data. The following is a picture of the data retrieval process that the author did:

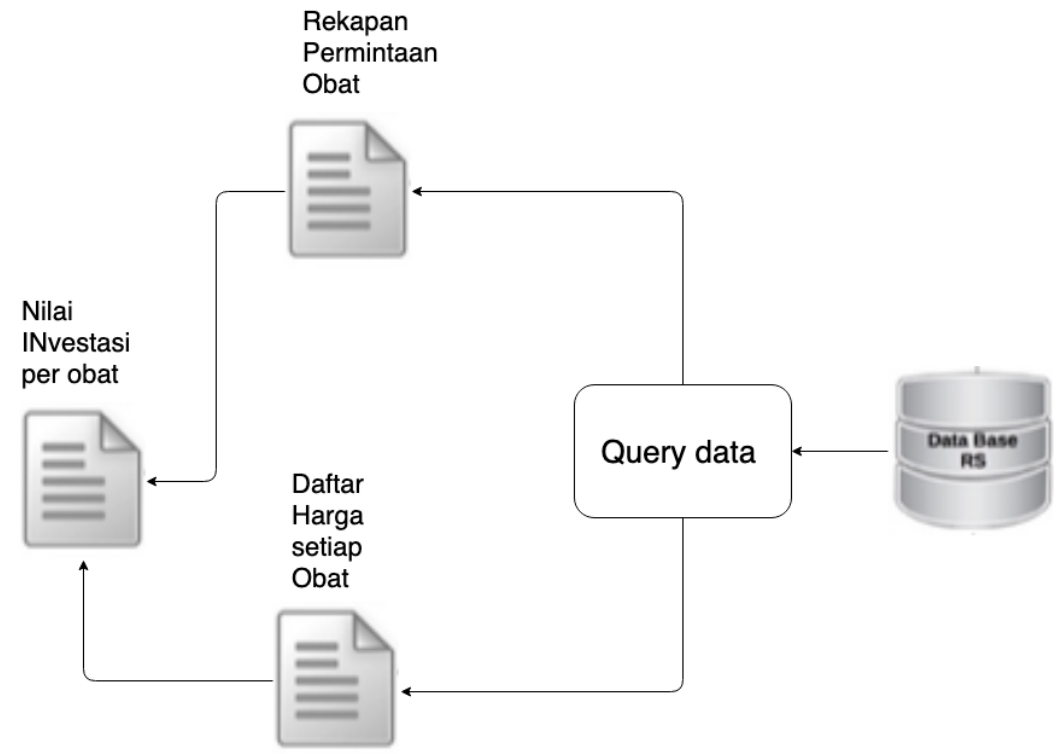

Figure 1 Flow of Data Retrieval Process

\subsection{Data Analysis}

The analysis method used in this research is quantitative analysis. In the drug classification process that is carried out, it contains the output of drug classification by dividing the drug into groups $\mathrm{A}, \mathrm{B}$ and $\mathrm{C}$. The next process is to carry out the optimization process of drug prediction using the SVR method by adding a process to the preproseccing data. The following is the flow of the analysis carried out:

a. Analysis on the classification process can be described in the following flow

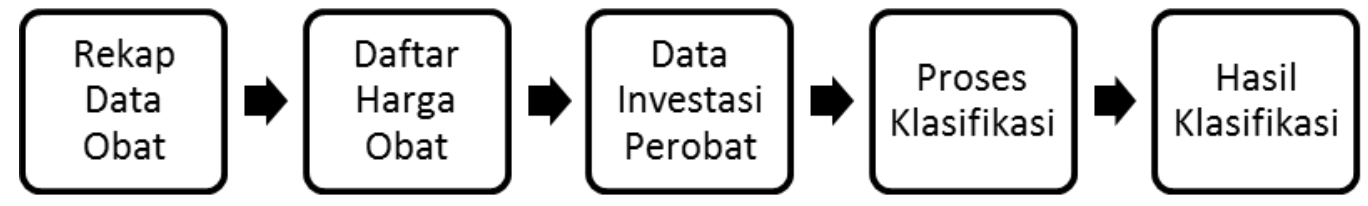

Figure 2 Classification Process with ABC Analysis

From the picture above, an explanation can be taken that the drug classification process is based on a recap of drug data and drug prices. Both variables are used to find the investment value per drug. The data are sorted from the highest level to the lowest level based on the investment value and calculate the cumulative investment value and the cumulative presentation. The final stage is the classification process and obtaining the results of dividing the drugs into groups $\mathrm{A}, \mathrm{B}$ and $\mathrm{C}$.

b. Data Processing Methods for Prediction

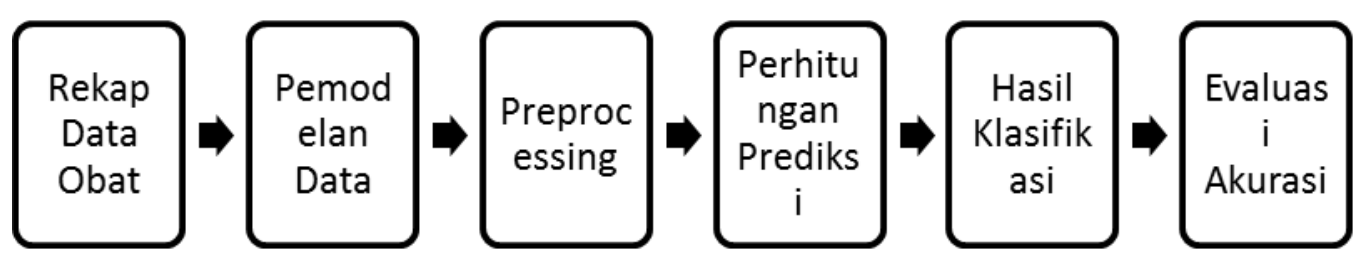

Figure 3 Data Processing Methods for prediction 


\subsection{Research Flow}

The research flow to be carried out is as follows:

1. Identification of problems, in the process of identifying problems in the selection and formulation of problems and identification of operational definitions of the problems at hand.

2. Literature review, line how to find data sources, data examples, determining research objects and the type of dataset used.

3. Determination of algorithms / methods, selection of algorithms that are relevant or related to research at this stage. There is also a determination of algorithm variations, and also the parameters that will be used in the algorithm.

4. Data collection, when lagorithms have been obtained, then how to collect data both from the type of dataset, the number of datasets and the required dataset variations.

5. Data processing, in data processing there are several detailed steps taken, namely: Performing queries, preprocessing with liner scaling and normalization.

6. The forecasting process, the forecasting process using the SVR method is carried out to predict drugs and obtain optimal results by comparing preprocessing normalization and linear scaling.

7. The process of drawing conclusions and evaluations, in the conclusion presenting the results of the research that has been done and how the evaluation should be carried out. 
ISSN : 1978 -8282, Online ISSN: 2655-4275

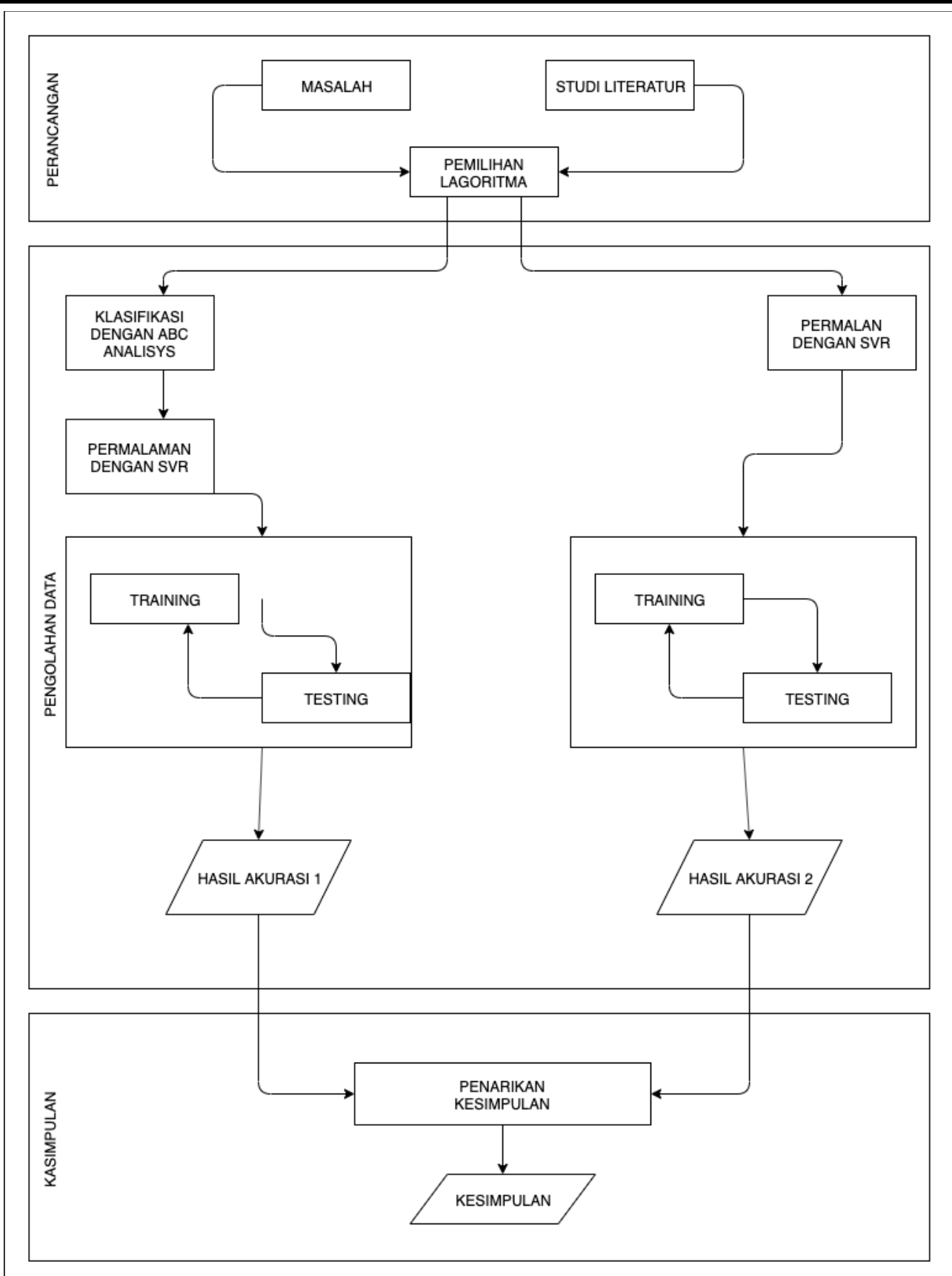

Figure 4 Flow of research process

\section{RESULTS AND DISCUSSION}

\subsection{Anlisisys ABC Classification}

The results of the classification process carried out by the author using the $\mathrm{ABC}$ analysis method is to divide into three groups, namely A, B and C. The results that the authors get are in accordance with the data in table 1:

Table 1. ABC Classification results

\begin{tabular}{|l|r|r|r|r|}
\hline Kategori & \multicolumn{1}{c|}{$\begin{array}{c}\text { Jumlah } \\
\text { Item }\end{array}$} & $\begin{array}{c}\text { Presentase } \\
\text { Jumlah Item }\end{array}$ & $\begin{array}{c}\text { Total Investasi } \\
\text { (dalam Rp) }\end{array}$ & \multicolumn{1}{c|}{$\begin{array}{c}\text { Presentase Total } \\
\text { Investasi }\end{array}$} \\
\hline A & 276 & $22,96 \%$ & 4.813 .997 .261 & $79,943 \%$ \\
\hline B & 389 & $33,11 \%$ & 905.950 .285 & $15,045 \%$ \\
\hline C & 528 & $43,93 \%$ & 301.849 .247 & $5,013 \%$ \\
\hline Jumlah & $\mathbf{1 2 0 2}$ & $\mathbf{1 0 0 \%}$ & $\mathbf{6 . 0 2 1 . 7 9 6 . 7 9 3}$ & $\mathbf{1 0 0 \%}$ \\
\hline
\end{tabular}




\subsection{1. $\quad$ Forecasting Process Uses Classification Result Data}

The process of forecasting carried out by the author is to use a sample data of 5 drugs with the highest investment, namely drugs that are classified as $\mathrm{A}$, the prediction test is carried out by the fold crossover method. The parameters used are $\mathrm{C}=1, \mathrm{C}=10$ and $\mathrm{C}=100$ and $\varepsilon=0.1$.

Table 2. Test results for 5 drug items

\begin{tabular}{|l|l|l|l|}
\hline \multirow{2}{*}{ Medicine Name } & \multicolumn{3}{c|}{ MAPE (in \%) } \\
\cline { 2 - 4 } & $\mathbf{C = 1}$ & $\mathbf{C}=\mathbf{1 0}$ & $\mathbf{C = 1 0 0}$ \\
\hline CEFAT CAP 500MG & 45,37 & 43,75 & 42,69 \\
\hline $\begin{array}{l}\text { CEFILA 100MG CAP } \\
@ \text { 30S }\end{array}$ & 34,26 & 32,93 & 33,15 \\
\hline $\begin{array}{l}\text { CLOPIDOGREL TAB } \\
\text { 75MG@ 30 }\end{array}$ & 52,90 & 51,13 & 50,66 \\
\hline $\begin{array}{l}\text { GOOD LIFE GCM } \\
\text { FORTE @ 30S }\end{array}$ & 34,75 & 34,39 & 34,61 \\
\hline $\begin{array}{l}\text { SEROLIN 30 MG 2X21 } \\
\text { TAB }\end{array}$ & 40,38 & 39,72 & 39,49 \\
\hline
\end{tabular}

From the tests conducted by the authors, the MAPE of each drug is quite high, namely an average of above $20 \%$

\subsection{2. $\quad$ The Forecasting Process Uses Preprocessing Linear Scaling}

The forecast process uses linear preprocessing using one example of drug data, namely CEFAT CAP 500MG, the drug shows that the pattern of demand data can be seen in table 3 below:

Table 3 Statistical description of CEFAT CAP 500MG

\begin{tabular}{|l|l|c|}
\hline MIn & Max & Score \\
\hline 208 & 490.2 & 759 \\
\hline
\end{tabular}

The experiment conducted by the author is to use the K-Fold crossover with a value of $K=5$ so that dividing it into 5 equal blocks has the same data length.

Table 4 Test Results (Normalization Data)

\begin{tabular}{|c|c|c|c|}
\hline TEST TO & MAPE (\%) & & \\
\hline & $\begin{aligned} \mathrm{C}= & 1 \text { dan } \varepsilon \\
& =0.1\end{aligned}$ & $\begin{array}{c}\mathrm{C}=10 \text { dan } \varepsilon \\
=0.1\end{array}$ & $\begin{array}{c}\mathrm{C}=100 \mathrm{dan} \\
\varepsilon=0.1\end{array}$ \\
\hline $\mathbf{1}$ & 15,86 & 15,77 & 16,33 \\
\hline 2 & 16,89 & 14,7 & 14,08 \\
\hline 3 & 20,0 & 16,75 & 16,61 \\
\hline 4 & 28,68 & 22,62 & 22,88 \\
\hline 5 & 17,72 & 17,73 & 18,03 \\
\hline Average & 19,83 & 17,51 & 17,59 \\
\hline
\end{tabular}

In accordance with the test results in table 4, the lowest MAPE is 18.09 with $\mathrm{C}=10$ and $\varepsilon=$ 0.1 . These results are more optimal than the SVR forecast without data preprocessing.

\subsubsection{Data Normalization Testing Process}

The forecast process uses linear preprocessing using one example of drug data, namely CEFAT CAP 500MG, the drug shows that the pattern of demand data can be seen in table 3 below.

Table 5 Statistical description of CEFAT CAP 500MG

\begin{tabular}{|c|c|c|c|c|c|}
\hline MIn & Max & Median & Mean & $3^{\text {rd }} \mathrm{Qu}$ & Max \\
\hline 208 & 490.2 & 759 & 584.7 & 684 & 951 \\
\hline
\end{tabular}

The experiment conducted by the author is to use the K-Fold crossover with a value of $\mathrm{K}=5$ so that dividing it into 5 equal blocks has the same data length. 
Table 6 Test Results (Linear scaling data)

\begin{tabular}{|c|c|c|c|}
\hline TEST TO & MAPE $(\%)$ & C= $=100$ dan \\
& $\begin{array}{c}\mathrm{C}=1 \text { dan } \varepsilon \\
=0.1\end{array}$ & $\begin{array}{c}\mathrm{C}=0.1 \\
\varepsilon=0.1\end{array}$ \\
\hline $\mathbf{1}$ & 15,86 & 15,69 & 15,65 \\
\hline $\mathbf{2}$ & 15,56 & 15,75 & 15,66 \\
\hline $\mathbf{3}$ & 19,22 & 18,68 & 18,63 \\
\hline $\mathbf{4}$ & 26,64 & 25,89 & 26,75 \\
\hline $\mathbf{5}$ & 17,42 & 17,43 & 17,44 \\
\hline Average & 18,09 & 18,69 & 18,83 \\
\hline
\end{tabular}

In accordance with the test results in table 5, the lowest MAPE is 18.09 with $\mathrm{C}=10$ and $\varepsilon=$ $17,51 \%$. These results are more optimal than the SVR forecast with ABC classification and normalization data.

\subsection{Comparison Chart}

Based on research with the case studies that the author describes, a calculation comparison chart is produced which is shown in the following graph:

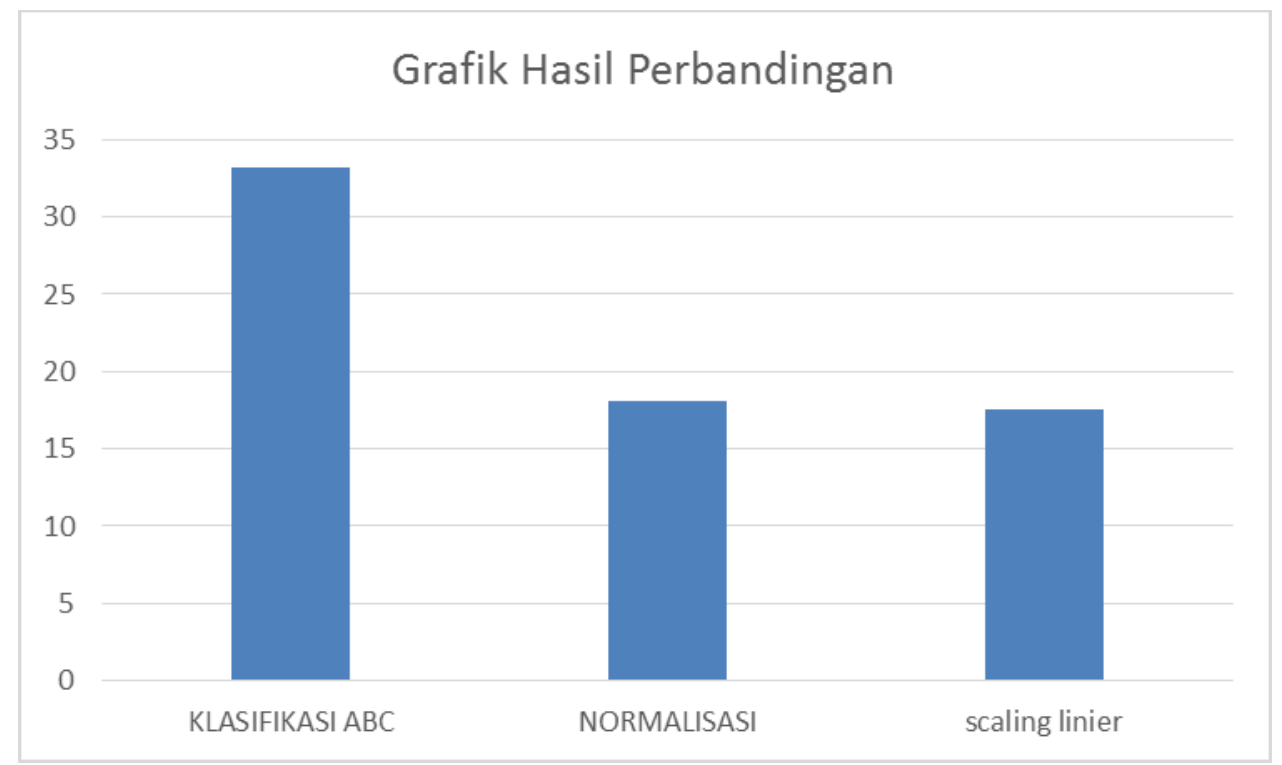

Figure 5 Comparison Result Graph

\section{CONCLUSION}

The results of the research for the optimization of drug sales forecasting using SVR is by using the data preprocessing process with linear scaling to get more optimal results, namely with MAPE $17.51 \%$, the lift is less than using preprocessing data with normalization, namely getting the MAPE value 18, 09\% and using the ABC analysis classification with a MAPE value of $33.15 \%$.

\section{SUGGESTED}

In further research, it is necessary to modify the kernel used, in this study the researchers used the RBF kernek and got the results that to optimize or maximize forecasts using SVR was to add preprocessing data, namely by using linear scaling. For the classification that the author uses is the $\mathrm{ABC}$ analysis method for further research, it can use a different classification to perform forecast optimization experiments using the SVR method. 


\section{REFERENCES}

[1] Santoso, B. 2007. Data Mining Teknik Pemanfaatan Data untuk Keperluan Bisnis. Yogyakarta: Graha Ilmu.

[2] Smola, A.J. dan Scholkopf, B. 2003. A Tutorial on Support Vector Regression. Technical Report, Neurocolt.

[3] Santoso, B. 2007. Data Mining Teknik Pemanfaatan Data untuk Keperluan Bisnis. Yogyakarta: Graha Ilmu.

[4] Smola, A.J. dan Scholkopf, B. 2003. A Tutorial on Support Vector Regression. Technical Report, Neurocolt.

[5] Kumar, S., \& Chakravarty, A. (2015). ABC-VED analysis of expendable medical stores at a tertiary care hospital. Medical Journal Armed Forces India, 71(1), 24-27. doi:10.1016/j.mjafi.2014.07.002Lamport, L., 1994, LaTeX: A Document Preparation System, Second Edition, Addison Wiley, Canada

[6] Er, M., Laili, E. N., \& Renny, P. K. (2011). Classification of Hospital Pharmaceutical Drug Inventory Items by Combining $\mathrm{ABC}$ Analysis and Fuzzy Classification. International Conference on Advanced Computer Science and Information System (ICACSIS 2011), 978979.

[7] Uthayakumar, R., \& Priyan, S. (2013). Pharmaceutical supply chain and inventory management strategies for optimization: A study on pharmaceutical company and hospital. Operations Research for Health Care. doi:10.1016/j.orhc.2013.08.001

[8] Kelle, P., Woosley, J., \& Schneider, H. (2012). Pharmaceutical supply chain specifics and inventory solutions for a hospital case. Operations Research for Health Care, 1(2-3), 54-63. doi:10.1016/j.orhc.2012.07.001

[9] Shiau, J.-Y., Li, X., \& Zheng, M.-J. (2012). Drug Inventory Control For Outpatien Services. Logistics Management, (July), 16-18.

[10] Fruggiero, F., Iannone, R., Martino, G., Miranda, S., \& Riemma, S. (2012). A forecast model for pharmaceutical requirements based on an artificial neural network. Service Operations and Logistics, and Informatics (SOLI), 2012 IEEE International Conference on, 263-268.

[11] Makridakis, S. (1986). The art and science of forecasting An assessment and future directions. International Journal of Forecasting, 2(1), 15-39. doi:10.1016/01692070(86)90028-2

[12] Scholz-Reiter, B., Heger, J., Meinecke, C., \& Bergmann, J. (2012). Integration of demand forecasts in $\mathrm{ABC}-\mathrm{XYZ}$ analysis: practical investigation at an industrial company.

[13] Vapnik, V. N. (1999). An overview of statistical learning theory. IEEE Transactions on Neural Networks / a Publication of the IEEE Neural Networks Council, 10(5), 988-999. doi:10.1109/72.788640

[14] Lamport, L., 1994, LaTeX: A Document Preparation System, Second Edition, Addison Wiley, Canada

[15] Novianti, F., \& Purnami, S. (2016). Analisis Diagnosis Pasien Kanker Payudara Menggunakan Regresi Logistik dan Support Vector Regression (SVR) Berdasarkan Hasil Mamografi. JURNAL SAINS DAN SENI.

[16] Suwardika, G. (2016). Pengelompokkan dan Klasifikasi Penggunaan Kontrasepsi di Indonesia. Jurnal matematika, Sains, dan Teknologi. 